\title{
Analisiss Kapasitas Pajak Daerah Kabupaten dan Kota Propinsi Nusa Tenggara Barat
}

\author{
Wahidin*, Musta'in, Yusuf Hasbullah \\ Fakultas Ekonomi dan Bisnis - Universitas Mataram \\ *Coresponding Email: wahidin.feb@unram.ac.id
}

\begin{tabular}{ll}
\hline \multicolumn{1}{c}{ Info Artikel } & \multicolumn{1}{c}{ ABSTRAK } \\
\hline $\begin{array}{l}\text { Kata Kunci: } \\
\text { Pajak Daerah, Pendapa- } \\
\text { tan per kapita, Sektor }\end{array}$ & $\begin{array}{l}\text { Ruang lingkup penelitian ini menganalisis pengaruh pendapa- } \\
\text { Ekonomi }\end{array}$ \\
pajak daerah. Tujuannya: untuk menganalisis pengaruh pen- \\
dapatan per kapita, sektor industri, sektor perdagangan, sektor \\
akomodasi dan penyedia makanan minuman, dan sektor infor- \\
masi dan komunikasi terhadap kapasitas Pajak Daerah. \\
Variabel penelitian yaitu: pendapatan per kapita, PDRB \\
sektor industri, PDRB sektor perdagangan, PDRB sektor ako- \\
modasi dan penyedia makanan minuman, PDRB sektor infor- \\
masi dan komunikasi. Pengumpulan data dilakukan dengan \\
menggunakan metode dokumentasi. Analisi data dilakukan \\
dengan menggunakan analisis Regresi berganda data panel. \\
Metode data panel yang dipakai adalah metode Random Ef- \\
fect. \\
Hasil penelitian: pendapatan per kapita dan sektor industri \\
berpengaruh secara tidak signifikansi terhadap pajak daerah. \\
Sektor perdagangan, sektor akomodasi dan penyedia makanan \\
minuman dan sektor informasi dan komunikasi berpengaruh \\
secara signifikansi terhadap pajak daerah. Sektor perdagangan \\
walaupun pengaruhnya secara signifikansi, namun ber- \\
pengaruh negatif.
\end{tabular}

ABSTRAK

Keywords:

Local Taxes, Per capita

Income, Economic Sector
The scope of this study analyzes the effect of per capita income and economic sectors on local tax capacity. The objective: to analyze the effect of per capita income, the industrial sector, the trade sector, the accommodation sector and food and beverage providers, and the information and communication sector on the capacity of local taxes.

The research variables were: per capita income, industrial sector GDP, trade sector GRDP, accommodation sector GDP and food and beverage providers, information and communication 
sector GDP. The data was collected using the documentation method. Data analysis was performed using panel data multiple regression analysis. The panel data method used is the Random Effect method.

Research results: per capita income and the industrial sector have no significant effect on local taxes. The trade sector, the accommodation sector and food and beverage providers and the information and communication sector have a significant effect on local taxes. Even though the trade sector is significant, it has a negative effect.

\section{PENDAHULUAN}

\section{Latar Belakang}

Pembangunan ekonomi daerah saat ini menuntut pemerintah maupun masyarakat untuk mengembangkan dan memanfaatkan potensi-potensi yang dimiliki oleh suatu daerah dalam rangka menunjang perekonomian kearah yang lebih baik. Pelaksanaan otonomi daerah yang dititikberatkan pada kabupaten/kota dimulai dengan adanya penyerahan sejumlah kewenangan atau urusan dari pemerintah pusat ke pemerintah daerah yang bersangkutan. Otonomi daerah dan desentralisasi fiskal memberikan sebuah tanggung jawab yang lebih besar kepada pemerintah daerah dalam menyediakan barang jasa publik. Disisi lain, pemerintah daerah memiliki kekuatan yang lebih besar untuk mengatur dan mengumpulkan penerimaan sendiri, khususnya dalam hal perpajakan dan retribusi.

Guna mewujudkan penyelengaraan otonomi daerah yang bertanggung jawab untuk mengatur dan mengurus sendiri suatu daerah, perlu dilakukan perluasan objek pajak daerah dan retribusi daerah dan pemberian diskresi dalam penetapan tarif serta kebijakan pajak daerah dan retribusi daerah dilaksanakan berdasarkan prinsip demokrasi, pemerataan dan keadilan, peran serta masyarakat dan akuntabilitas dengan memperhatikan potensi daerah.
Walaupun sudah dalam sistem desentralisasi, pemerintah pusat masih memiliki tanggung jawab dalam hal memberikan sejumlah dana kepada daerah yang tujuan utamanya adalah redistribusi, yaitu mengatasi ketimpangan fiskal antardaerah. Namun banyak contoh kasus yang daerah-daerahnya masih sangat tergantung pada transfer fiskal dari pemerintah pusat dibanding berusaha menggali pendapatan dari sumber pemerintah daerah sendiri sebagaimana amanat desentralisasi itu sendiri.

Kebijakan desentralisasi fiskal mengharapkan ketergantungan pemerintah daerah terhadap pemerintah pusat berkurang, sehingga mampu mencapai kemandirian daerah sebagaimana tujuan otonomi daerah itu sendiri. Idealnya, semua pengeluaran tambahan pemerintah daerah dapat dipenuhi dengan menggunakan Pendapatan Asli Daerah (PAD), sehingga daerah benar-benar otonom dan tidak tergantung lagi kepada pemerintah pusat. Menurut McLean (2005), pemerintah daerah seharusnya dibiayai sebanyak mungkin melalui pajak dan seminimal mungkin dari dana hibah pemerintah pusat.

Ketergantungan kabupaten dan kota di propinsi Nusa Tenggara Barat masih tinggi terhadap pemerintah pusat. Hal ini tercermin dalam kontribusi Pendapatan Asli Daerah untuk semua kabupaten dan kota terhadap pendapatan daerah 


\section{Elastisitas - Jurnal Ekonomi Pembangunan \\ Vol. 3 No. 2, September 2021}

masih sangat rendah (kurang dari $26 \%$ ). Sumber; BPS Kabupaten dan Kota Dalam Angka 2019, diolah

Pajak daerah merupakan salah satu sumber penerimaan PAD yang paling potensial dalam memperbesar porsi PAD. Pajak memainkan peran yang penting dalam proses untuk menghasilkan penerimaan dan untuk menjalankan berbagai aktivitas dalam perekonomian. Pajak daerah merupakan iuran wajib yang dilakukan oleh orang pribadi atau badan di wilayah tersebut kepada pemerintah daerah tanpa adanya imbalan langsung yang seimbang yang sifatnya dapat dipaksakan berdasarkan aturan perundangan yang berlaku. Dengan demikian, kewenangan pemerintah daerah dalam hal mengumpulkan pajak seharusnya menjadi modal utama dalam upaya meningkatkan PAD untuk membiayai kegiatan pembangunan.

Pajak daerah diharapkan menjadi sumber terbesar bagi PAD. Kenyataannya, data realisasi penerimaan Pajak Daerah kabupaten dan kota di propinsi Nusa Tenggara Barat dari tahun ke tahun menunjukkan kontribusi yang masih rendah terhadap Pendapatan Asli Daerah. Tahun 2018, kontribusi Pajak Daerah terhadap PAD sebagai berikut: Kota Mataram sebesar 40,68 \%; kabupaten Lombok Barat sebesar 35,18 \%; kabupaten Lombok Tengah sebesar 36,60\% ; kabupaten Lombok Timur sebesar 23,14 \%; kabupaten Lombok Utara sebesar 52,50 \%; kabupaten Sumbawa Barat sebesar 35,42 \%; kabupaten Sumbawa sebesar 24,72 \%; kabupaten Dompu sebesar 8,16\%; kabupaten Bima sebesar 9,51\%; dan kota Bima hanya sebesar $22,14 \%$.

Gambaran data kontribusi Pajak Daerah terhadap PAD di masing-masing kabupaten dan kota di propinsi Nusa Tenggara Barat di atas masih berada di bawah 50 persen. Hal ini menunjukkan bahwa kemampuan Pajak Daerah dalam pembiayaan pemerintah daerah kabupaten dan kota di propinsi NTB masih rendah.
Ini berarti kemandirian pemerintah daerah kabupaten dan kota di propinsi NTB belum dapat terwujud. Oleh karena itu berbagai upaya harus terus dilakukan oleh pemerintah daerah kabupaten dan kota agar kapasitas Pajak Daerah dapat berperan lebih besar lagi dalam pembiayaan pemerintah daerah. Potensi pajak daerah berkaitan langsung dengan aktivitas ekonomi sektoral dan sistem serta kemampuan aparatur pemerintah daerah untuk menggali sumber-sumber pajak potensial yang dapat dijadikan sebagai basis utama Pendapatan Asli Daerah (PAD)

Upaya-upaya ini harus dilakukan pada berbagai faktor yang menentukan besar-kecilnya pajak daerah. Faktor-faktor yang menentukan besar-kecilnya pajak daerah, secara teoritis antara lain: pendapatan perkapita, Produk Domestik Regional Bruto (PDRB) sektor-sektor yang menjadi sumber pajak daerah yaitu sektor industri, sektor perdagangan, sektor penyedia akomodasi dan makanan minuman, sektor informasi dan komunikasi.

PDRB per kapita menggambarkan tingkat pembangunan (level of development). Semakin tinggi tingkat pembangunan akan mendorong kemampuan membayar yang lebih tinggi dan mengumpulkan hasil pajaknya, sebagaimana semakin tinggi permintaan relatif atas pendapatan, baik barang maupun jasa publik (Bird et al., 2008). Sehingga secara teori, kapasitas pajak dipengaruhi oleh tingkat pembangunan di masing-masing daerah. Sehingga hipotesisnya, PDRB berkorelasi secara positif terhadap derajat potensi pajak daerah. Argumentasinya adalah semakin tinggi tingkat pembangunan ekonomi di suatu daerah akan diikuti dengan meningkatnya kecakapan masyarakat, pergerakan uang, dan penegakan hukum yang lebih baik, sehingga akan membawa pada meningkatnya kapasitas pajak daerah.

Demikian juga perekonomian yang didominasi oleh sektor sekunder dan 


\section{Elastisitas - Jurnal Ekonomi Pembangunan \\ Vol. 3 No. 2, September 2021}

tersier (industri dan perdagangan, dan lain-lain) meningkatkan basis pajak daerah, sehingga semakin besar kesempatan dan kemudahan memungut pajak. Dan pada akhirnya kapasitas pajak daerah semakin tinggi.

\section{Perumusan Masalah}

Berdasarkan lata belakang di atas, maka masalah yang ingin dianalisis dari penelitian ini adalah sebagai berikut:

"Apakah pendapatan perkapita, sektor industri, sektor perdagangan, sektor akomodasi dan penyedia makanan minuman, sektor informasi dan komunikasi, berpengaruh secara signifikansi terhadap kapasitas Pajak Daerah".

\section{Tujuan Penelitian}

Berdasarkan perumusan masalah diatas, maka tujuan yang ingin dicapai dari penelitian ini adalah sebagai berikut: "Untuk menganalisis pengaruh pendapatan per kapita, sektor industri, sektor perdagangan, sektor akomodasi dan penyedia makanan minuman, dan sektor informasi dan komunikasi terhadap kapasitas Pajak Daerah.

\section{Urgensi Penelitian}

Mengapa analisis kapasitas pajak daerah menjadi begitu penting?

a. Otonomi daerah mengharapkan pemerintah daerah mempunyai kemandirian dalam pembiayaan daerah.

b. Pendapatan Asli Daerah (PAD) merupakan salah satu sumber pendapatan daerah sebagai sumber pembiayaan daerah. PAD menjadi indikator bagi kemandirian daerah dalam pembiayaan.

c. Pajak Daerah merupakan sumber utama bagi PAD. Sehingga untuk meningkatkan PAD harus dilakukan upaya pada faktor-faktor yang menentukan kapasitas pajak daerah.

\section{State of the Art}

Penyusunan kajian ini mengambil beberapa referensi penelitian-penelitian terdahulu.

Sherly Ering, dkk (2016), tujuan penelitian adalah mengkaji faktor-faktor yang dapat menjelaskan potensi pajak di Sulawesi Utara yang dapat memperkuat kapasitas fiskalnya. Metode pengumpulan data (1) metode wawancara, dan (2) dokumentasi, Metode analisis: analisis regresi data panel. Hasil penelitian: sejumlah faktor penentu potensi pajak daerah yaitu pendapatan per kapita, sektor pertanian, dan jumlah siswa SMA, sedangkan jumlah pekerja tidak signifikan.

Gebriany Pirade Wenur, dkk (2016), tujuan penelitian adalah mengkaji potensi pajak daerah untuk proyeksi Pendapatan Asli Daerah (PAD) di Kota Bitung propinsi Sulawesi Utara. Metode pengumpulan data: wawancara dan dokumentasi. Metode analisis: Analisis Komparatif, Analisis Matriks Pertumbuhan dan Kontribusi, dan Analisis Potensi Pajak Daerah. Hasil penelitian: Kota Bitung memiliki potensi pajak daerah yang belum dioptimalkan oleh pemerintah daerah (DIPENDA). Pada tahun 2016 hingga 2020 pajak daerah potensi pendapatan telah diproyeksikan naik 25 persen.

\subsection{Pendapatan Asli Daerah}

Menurut Undang-Undang Nomor 28 Tahun 2009 tentang Pajak Daerah dan Retribusi Daerah, dinyatakan bahwa Pendapatan Asli Daerah (PAD) adalah sumber keuangan daerah yang digali dari wilayah daerah yang bersangkutan yang terdiri dari hasil pajak daerah, hasil retribusi daerah, hasil pengelolaan kekayaan daerah yang dipisahkan dan lain-lain pendapatan asli daerah yang sah.

Pendapatan daerah terdiri dari :

a. Hasil Pajak Daerah;

b. Hasil Retribusi Daerah;

\section{TINJAUAN PUSTAKA}


c. Hasil perusahaan milik daerah dan hasil pengelolaan kekayaan daerah yang dipisahkan;

d. Lain-lain pendapatan asli daerah lainnya yang sah.

\section{Pajak Daerah}

Pajak daerah menurut (Mardiasmo, 2013) mengemukakan bahwa "pajak daerah adalah kontribusi wajib kepada daerah yang terutang oleh orang pribadi atau badan yang bersifat memaksa berdasarkan Undang-Undang, dengan tidak mendapatkan imbalan secara langsung dan digunakan untuk keperluan daerah bagi sebesar-besarnya kemakmuran rakyat.

Abuyamin dalam Bernardin dan Sofyan (2017:277) menyatakan bahwa "pajak daerah adalah kontribusi wajib pajak daerah yang terutang oleh orang pribadi atau badan yang bersifat memaksa berdasarkan undang-undang dengan tidak mendapatkan imbalan secara langsung dan digunakan untuk keperluan daerah bagi sebesar-besarnya kemakmuran rakyat". Pajak daerah yaitu kontribusi wajib pajak orang pribadi atau badan yang kepada pemerintah daerah yang digunakan untuk kesejahteraan masyarakat daerah tersebut dengan sifat memaksa sesuai dengan peraturan undang-undang yang berlaku.

Pajak adalah iuran kepada negara (yang dapat dipaksakan) yang terutang oleh yang wajib membayarnya menurut peraturan-peraturan, dengan tidak mendapat prestasi kembali, yang langsung dapat ditunjuk, dan yang gunanya adalah untuk membiayai pengeluaran-pengeluaran umum berhubung tugas negara untuk menyelenggarakan pemerintahan. (Sumarsan, 2013: 3). Dari definisi tersebut, dapat disimpulkan bahwa pajak memiliki unsur unsur: (1) iuran dari rakyat kepada negara, yang berhak memungut pajak hanyalah negara. Iuran tersebut berupa uang (bukan barang); (2) berdasarkan undang-undang, pajak dipungut berdasarkan atau dengan kekuatan undangundang serta aturan pelaksanaannya; (3) tanpa jasa timbal atau kotraprestasi dari negara yang secara langsung dapat ditunjuk. Dalam pembayaran pajak tidak dapat ditunjukkan adanya kontraprestasi individual oleh pemerintah; (4) digunakan untuk membiayai rumah tangga negara, yakni pengeluaran-pengeluaran yang bermanfaat bagi masyarakat luas.

Pemerintah memerlukan penerimaan dari pajak untuk membiayai pengeluaran publiknya, terlepas dari apakah pajak tersebut ditujukan untuk efisiensi atau keadilan sosial (Hillman, 2003 dalam Sherly Ering, dkk, 2016). Berdasarkan Undang-Undang (UU) No. 28 Tahun 2009 tentang Pajak Daerah dan Retribusi Daerah, pemerintah daerah memiliki kewenangan lebih luas untuk memungut pajak daerah dan retribusi daerah berdasarkan prinsip-prinsip pungutan daerah yang baik. Selain itu, pemerintah daerah juga diberi kewenangan membuat kebijakan pengenaan pajak dan retribusi, mengelola pajak pusat yang dialihkan menjadi pajak daerah, dan menambah jenis-jenis pajak baru untuk memperluas basis pajak di daerah. Akan tetapi, berbagai upaya di bidang perpajakan dengan menggali potensi cakupan pajak (tax coverage) dan meningkatkan kepatuhan pajak (tax compliance) dari masyarakat seringkali menghadapi berbagai hambatan, baik dari wajib pajak (masyarakat), aparatur pajak, maupun sistem perpajakan itu sendiri. Oleh karena itu, permasalahan pajak harus ditangani secara sinergis dan komprehensif.

\section{Jenis Pajak Daerah}

Berdasarkan Undang-Undang Nomor 28 Tahun 2009, jenis pajak daerah yaitu: (1) Pajak Provinsi meliputi Pajak Kendaraan Bermotor, Bea Balik Nama Kendaraan Bermotor, Pajak Bahan Bakar Kendaraan Bermotor, Pajak Air Permukaan, serta Pajak Rokok. (2) Pajak Kabupaten/Kota meliputi Pajak Hotel, Pajak Restoran, Pajak Hiburan, Pajak Reklame, Pajak Penerangan Jalan, Pajak Mineral Bukan Logam dan Batuan, Pajak Parkir, Pajak Air Tanah, Pajak Sarang Burung Walet, Pajak 


\section{Elastisitas - Jurnal Ekonomi Pembangunan \\ Vol. 3 No. 2, September 2021}

Bumi dan Bangunan Perdesaan dan Perkotaan, serta Bea Perolehan Hak atas Tanah dan Bangunan

Khusus untuk daerah yang setingkat dengan daerah provinsi, tetapi tidak terbagi dalam daerah kabupaten/kota otonom. Misalnya, Daerah Khusus Ibukota Jakarta, jenis Pajak yang dapat dipungut merupakan gabungan dari Pajak untuk daerah provinsi dan Pajak untuk daerah kabupaten/kota (Pasal 2 ayat 5 Undangundang Pajak dan Retribusi Daerah No. 28 tahun 2009 ).

\section{Pemungutan Dan Penagihan Pajak Daerah}

Tata Cara Pemungutan Pajak Daerah

a. Pemungutan Pajak dilarang diborongkan

b. Setiap Wajib Pajak wajib membayar Pajak yang terutang berdasarkan surat ketetapan pajak atau dibayar sendiri oleh Wajib Pajak berdasarkan peraturan perundang-undangan perpajakan.

c. Wajib Pajak yang memenuhi kewajiban perpajakan berdasarkan penetapan Kepala Daerah dibayar dengan menggunakan SKPD atau dokumen lain yang dipersamakan

d. Dokumen lain yang dipersamakan berupa karcis dan nota perhitungan.

e. Wajib Pajak yang memenuhi kewajiban perpajakan sendiri dibayar dengan menggunakan SPTPD, SKPDKB, dan/atau SKPDKBT

Tata Cara Pembayaran Dan Penagihan Pajak Daerah

a. Kepala Daerah menentukan tanggal jatuh tempo pembayaran dan penyetoran pajak yang terutang paling lama 30 (tiga puluh) hari kerja setelah saat terutangnya pajak dan paling lama 6 (enam) bulan sejak tanggal diterimanya SPPT oleh Wajib Pajak

b. SPPT, SKPD, SKPDKB, SKPDKBT, STPD, Surat Keputusan Pembetulan, Surat Keputusan Keberatan, dan
Putusan Banding, yang menyebabkan jumlah pajak yang harus dibayar bertambah merupakan dasar penagihan pajak dan harus dilunasi dalam jangka waktu paling lama 1 (satu) bulan sejak tanggal diterbitkan.

c. Kepala Daerah atas permohonan Wajib Pajak setelah memenuhi persyaratan yang ditentukan dapat memberikan persetujuan kepada Wajib Pajak untuk mengangsur atau menunda pembayaran pajak, dengan dikenakan bunga sebesar $2 \%$ (dua persen) sebulan.

d. Pajak yang terutang berdasarkan SPPT, SKPD, SKPDKB, SKPDKBT, STPD, Surat Keputusan Pembetulan, Surat Keputusan Keberatan, dan $\mathrm{Pu}$ tusan Banding yang tidak atau kurang dibayar oleh Wajib Pajak pada waktunya dapat ditagih dengan Surat Paksa.

e. Penagihan pajak dengan Surat Paksa dilaksanakan berdasarkan peraturan perundang-undangan.

\section{Potensi (kapasitas) Penerimaan Pajak}

Potensi pajak sangat menentukan besarnya pajak daerah yang dapat dipungut, dengan demikian besarnya potensi pajak perlu diketahui untuk menetapkan besarnya target penerimaan pajak pada suatu periode. Merupakan hasil temuan pendataan di lapangan yang berkaitan jumlah serta frekuensi obyek pajak yang kemudian dikalikan dengan tarif dasar pajak. (Mardiasmo dan Makhfatih). Potensi pajak didefinisikan sebagai rasio pajak yang akan terjadi jika ekonomi menggunakan semua sumber daya dan kemampuan untuk mengumpulkan semua yang diperoleh pendapatan pajak dari hasil yang diberikan daerah tersebut. (Alfirman, 2003, dalam Gebriany Pirade Wenur, dkk. 2016)

\section{Hipotesis}




\section{Elastisitas - Jurnal Ekonomi Pembangunan \\ Vol. 3 No. 2, September 2021}

Berdasarkan tujuan penelitian dan penelitian terdahulu maka hipotesis penelitian ini adalah:

a. Pendapatan per kapita, sektor industri, sektor perdagangan, sektor penyedia makanan minuman, sektor informasi dan komunikasi secara parsial berpengaruh signifikan terhadap kapasitas pajak daerah.

b. Pendapatan per kapita, sektor industri, sektor perdagangan, sektor penyedia makanan minuman, sektor informasi dan komunikasi secara simultan berpengaruh signifikan terhadap kapasitas pajak daerah.

\section{METODE PENELITIAN}

\section{Jenis Penelitian}

Penelitian ini bertujuan untuk memberikan penjelasan tentang bagaimana pengaruh pendapatan per kapita, sektor industri, sektor perdagangan, sektor penyedia makanan minuman, informasi dan komunikasi terhadap kapasitas pajak daerah. Dengan tujuan penelitian tersebut, maka jenis penelitian yang digunakan adalah penelitian deskriptip yaitu penelitian yang memuat penjelasan secara sistematis terhadap fakta-fakta yang ada dan pengujian hipotesis (eksplanatory) yaitu suatu bentuk penelitian yang dilakukan untuk memberikan gambaran dan memberikan penjelasan pengaruh antar variabel melalui pengujian hipotesis

\section{Jenis Data dan Sumber Data}

Jenis data yang digunakan dalam penelitian ini adalah data sekunder yang bersumber dari hasil pencatatan yang sistematis berupa data runtut waktu (time series) dan data silang (cross-section). Data sekunder yang dikumpulkan yaitu 1) pajak daerah, 2) pendapatan per kapita, 3) PDRB sektor industri, 4) PDRB sektor perdagangan, 5) PDRB sektor penyedia makanan minuman, 6) PDRB sektor informasi dan komunikasi.

Data dipeoleh dari hasil publikasi Badan Pusat Statistik (BPS) kabupaten dan kota sepropinsi NTB, Dinas Pendapatan Daerah kabupaten dan kota, Dinas Perdagangan dan perindustrian kabupaten dan kota.

\section{Metode Pengumpulan Data}

Pengumpulan data penelitian dilakukan dengan menggunakan metode dokumentasi, yaitu teknik pengumpulan data dengan jalan membaca dan mencatat data- data yang diperoleh dari instansi-instansi terkait dan dari bahan-bahan yang berhubungan dengan masalah yang diteliti (Nazir, 2011: 127).

Pencatatan data yang telah dipublikasikan oleh BPS kabupaten dan kota, data publikasi Dispenda kabupaten dan kota, data publikasi dinas perindustrian dan perdagangan kabupaten kota propinsi NTB.

\section{Definisi Operasional Variabel}

Definisi operasional variabel adalah suatu definisi yang diberikan kepada suatu variabel dengan cara memberikan arti atau menspesifikasikan kegiatan atau memberikan suatu operasional untuk mengukur variabel atau konstruk tersebut (Nasir, 1999). Definisi operasional variabel dalam penelitian ini adalah:

a. Kapasitas Pajak Daerah adalah jumlah pajak daerah yang diterima oleh pemerintah daerah setiap tahun dalam satuan rupiah $(\mathrm{Rp})$

b. Pendapatan per kapita adalah PDRB per kapita dalam satu tahun dalam satuan rupiah (Rp.). PDRB per kapita adalah jumlah PDRB dibagi dengan jumlah penduduk

c. PDRB sektor industri adalah nilai produksi sektor industri dalam satu tahun dalam satuan rupiah ( $\mathrm{Rp})$ 


\section{Elastisitas - Jurnal Ekonomi Pembangunan \\ Vol. 3 No. 2, September 2021}

d. PDRB sektor perdagangan adalah nilai produksi sektor perdagangan dalam satu tahun dalam satuan rupiah $(\mathrm{Rp})$

e. PDRB sektor penyedia makanan minuman adalah nilai produksi sektor penyedia makanan minuman dalam satu tahun dalam satuan rupiah ( $R p)$

f. PDRB sektor informasi dan komunikasi adalah nilai produksi sektor informasi dan komunikasi dalam satu tahun dalam satuan rupiah ( $R p)$.

\section{Metode Analisis Data}

Analisis data yang digunakan dalam penelitian ini adalah analisis regresi linear berganda data panel dengan rumus sebagai berikut:

$$
\begin{aligned}
& \mathrm{Y}=\beta_{0}+\beta_{1} \mathrm{X}_{1}+\beta_{2} \mathrm{X}_{2}+\beta_{3} \mathrm{X}_{3}+ \\
& \beta_{4} \mathrm{X} 4+\beta_{5} \mathrm{X}_{5}+\mathrm{e} ;
\end{aligned}
$$

Dari persamaan di atas akan diestimasi dengan menggunakan metode Ordinary
Least Square (OLS). Pengujian statistik dilakukan dengan melihat uji-t dan uji-F. Keterangan:

$$
\begin{aligned}
& Y=\text { kapasitas pajak daerah } \\
& \mathrm{X}_{1}=\text { pendapatan per kapita } \\
& \mathrm{X}_{2}=\text { PDRB sektor industri } \\
& \mathrm{X}_{3}=\text { PDRB sektor perdagangan } \\
& \mathrm{X}_{4}=\text { PDRB sektor akomodasi dan } \\
& \text { penyedia makanan minuman } \\
& \mathrm{X}_{5}=\text { PDRB sektor informasi dan } \\
& \text { komunikasi } \\
& \text { Bo }=\text { Konstanta } \\
& \beta_{1}, \beta 2 \text {, dan } \beta 3=\text { Koefisien Regresi }
\end{aligned}
$$

\section{HASIL DAN PEMBAHASAN}

\section{Hasil Estimasi Persamaan Regresi}

Berdasarkan hasil pengolahan data dengan menggunakan metode: Panel EGLS (Cross-section random effects) diperoleh hasil sebagai berikut:

Tabel 1.

Hasil Analisis Kapasitas Pajak dengan Metode Panel EGLS

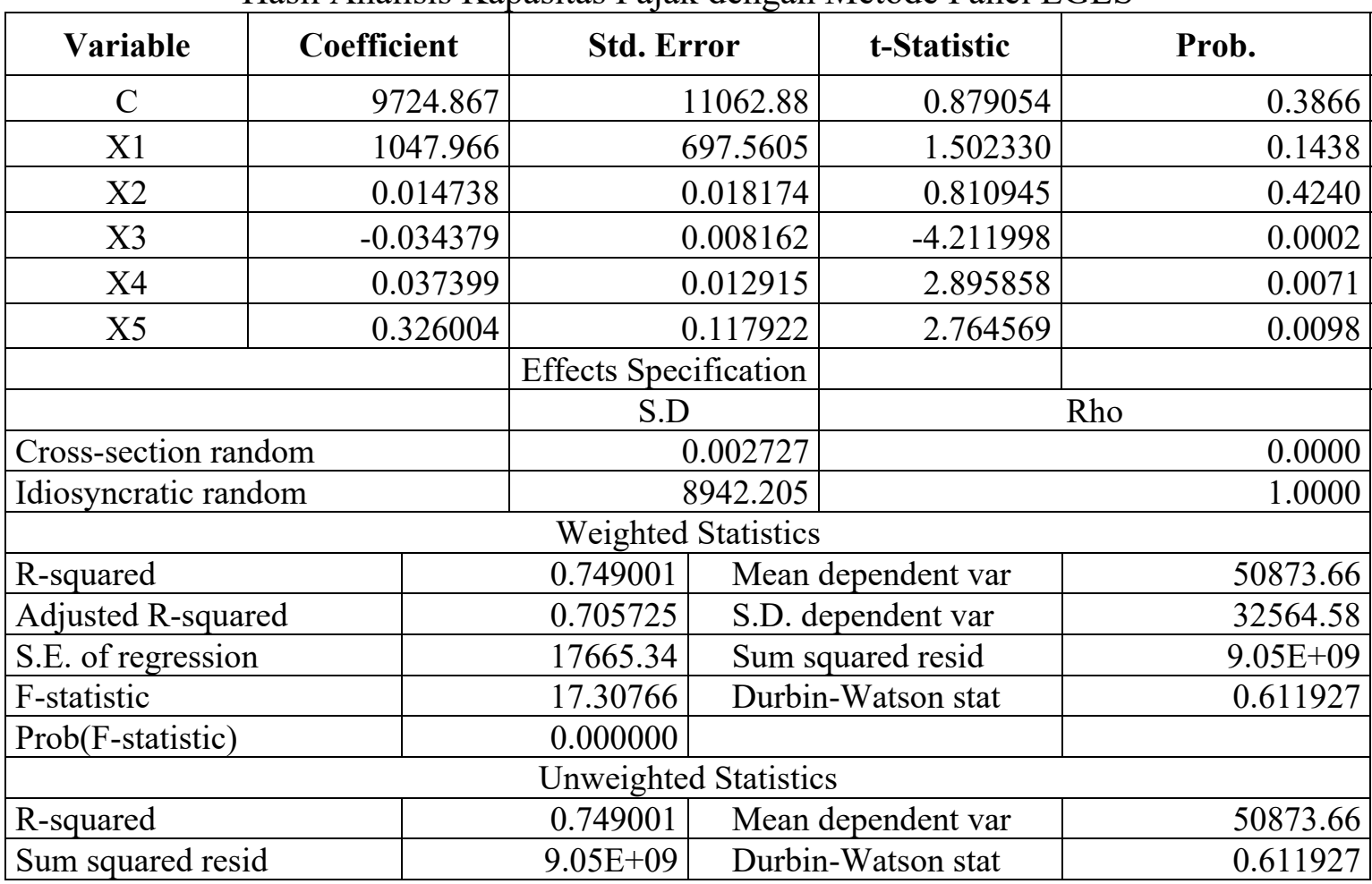

Sumber: Hasil olahan

Berdasarkan tabel regresi di atas terlihat bahwa R-squared sebesar 0,749001. Maka 


\section{Elastisitas - Jurnal Ekonomi Pembangunan \\ Vol. 3 No. 2, September 2021}

dapat diartikan bahwa variasi kapasitas pajak daerah mampu dijelaskan oleh pendapatan per kapita, sektor industri, sektor perdagangan, sektor akomodasi dan penyedia makanan minuman, sektor informasi dan komunikasi sebesar 74,90\%. Sisanya sebesar $25,10 \%$ variasi kapasitas pajak daerah dijelaskan oleh variabel lain di luar model ini, seperti jumlah penduduk, dan jumlah wajib pajak daerah. Dari table di atas dapat dilihat juga nilai Adjusted R-squared sebesar 0.705725, dapat diartikan bahwa variasi perubahan kapasitas pajak daerah dapat dijelaskan oleh pendapatan per kapita, sektor industri, sektor perdagangan, sektor akomodasi dan penyedia makanan minuman, sektor informasi dan komunikasi sebesar $70 \%$ dan sisanya $30 \%$ dapat dijelaskan oleh variabel independent lain di luar model.

Berdasarkan hasil table 4.1. diperoleh nilai probabilitas F-statistik sebesar 0,000000 lebih kecil dari tingkat sigifikansi $\alpha(0,05)$. Hal ini menunjukkan bahwa variabel pendapatan per kapita, sektor industri, sektor perdagangan, sektor akomodasi dan penyedia makanan minuman, sektor informasi dan komunikasi berpengaruh secara signifikansi terhadap kapasitas pajak daerah.

Berdasarkan hasil table 4.1 diperoleh nilai t-hitung untuk variabel pendapatan per kapita $\left(X_{1}\right)$ sebesar 1,5023 dan variabel sektor industri $\left(\mathrm{X}_{2}\right)$ sebesar 0,810945. Nilai t-hitung kedua variabel ini lebih kecil dari t- table sebesar 1,645. Dan nilai probabilita pendapatan per kapita $\left(\mathrm{X}_{1}\right)$ sebesar 0,4138, dan nilai probabilita sektor industri $\left(\mathrm{X}_{2}\right)$ sebesar 0,4240 . Nilai probabilita dua variabel ini lebih besar dari $\alpha(0,05)$. Hal ini menunjukkan bahwa pendapatan per kapita $\left(\mathrm{X}_{1}\right)$ dan sektor industri $\left(\mathrm{X}_{2}\right)$ berpengaruh tidak secara signifikansi terhadap kapasitas pajak daerah.

Diperoleh nilai t-hitung untuk variabel sektor perdagangan $\left(\mathrm{X}_{3}\right)$ sebesar 4,2119 , nilai t-hitung variabel sektor akomodasi dan penyedia makanan minuman
$\left(\mathrm{X}_{4}\right)$ sebesar 2,8958, nilai t-hitung variabel sektor informasi dan komunikasi ( $\left.\mathrm{X}_{5}\right)$ sebesar 2,7645. Nilai t-hitung ketiga variabel ini lebih besar dari t-tabel sebesar 1,645. Dan diperoleh pula nilai probabilitas sektor perdagangan $\left(\mathrm{X}_{3}\right)$ sebesar 0,0002 , nilai probabilitas sektor akomodasi dan penyedia makanan minuman $\left(\mathrm{X}_{4}\right)$ sebesar 0,0071 , dan nilai probalitas sektor informasi dan komunikasi (X5) sebesar 0.0098. nilai probabilitas ketiga variabel ini lebih kecil dari $\alpha(0,05)$. Hal ini menunjukkan bahwa variabel sektor perdagangan, sektor akomodasi dan penyedia makanan minuman, sektor informasi dan komunikasi berpengaruh secara signifikansi terhadap kapasitas pajak daerah. Sektor perdagangan berpengaruh secara signifikansi dan berkerolasi negatif.

Persamaan regresi hasil estimasi data panel model random effects adalah sebagai berikut

$\mathrm{Y}=9724.86+1047.96 * \mathrm{X} 1+0.0147 * \mathrm{X} 2$

$-0.03437 * X 3+0.03739 * X 4+$

$0.32600 * \mathrm{X} 5+[\mathrm{CX}=\mathrm{R}, \mathrm{ESTSMPL}=$ "2014 2019"]

Dari persamaan regresi di atas dapat disimpulkan:

1. $\beta_{0}=9724,866$, artinya apabila pendapatan per kapita, sektor industri, sektor perdagangan, sektor akomodasi dan penyedia makanan minuman, sektor informasi dan komunikasi sebesar 0 maka kapasitas pajak daerah sebesar 9724,866

2. $\beta_{1}=1047,96$, artinya setiap kenaikan pendapatan per kapita sebesar $1 \mathrm{Ru}-$ piah maka akan menaikkan kapasitas pajak daerah sebesar 1047,96 rupiah, dengan asumsi sektor industri, sektor perdagangan, sektor akomodasi dan penyedia makanan minuman, sektor informasi dan komunikasi, tetap.

3. $\beta_{2}=0,0147$, artinya setiap kenaikan PDRB sektor industri sebesar 1 juta, maka akan menaikkan kapasitas pajak 


\section{Elastisitas - Jurnal Ekonomi Pembangunan \\ Vol. 3 No. 2, September 2021}

daerah sebesar 0,0147 juta, dengan asumsi pendapatan perkapita, sektor perdagangan, sektor akomodasi dan penyedia makanan minuman, sektor informasi dan komunikasi, tetap.

4. $\beta_{3}=-0,03437$, artinya setiap kenaikan sektor perdagangan sebesar 1 juta, maka akan menurunkan kapasitas pajak daerah sebesar 0,03437 juta, dengan asumsi sektor industri, sektor akomodasi dan penyedia makanan minuman, sektor informasi dan komunikasi, tetap.

5. $\beta_{4}=0,03739$, artinya setiap kenaikan sektor akomodasi dan penyedia makanan minuman sebesar 1 juta, maka akan menaikkan kapasitas pajak daerah sebesar 0,03739 juta, dengan asumsi pendapatan per kapita, sektor industri, sektor perdagangan, sektor informasi dan komunikasi, tetap.

6. $\beta 5=0,32600$, artinya setiap kenaikan sektor informasi dan komunikasi sebesar 1 juta, maka akan menaikkan kapasitas pajak daerah sebesar 0,32600 juta, dengan asumsi pendapatan per kapita, sektor industri, sektor perdagangan, sektor akomodasi dan penyedia makanan minuman, tetap.

\section{Pembahasan}

Dari hasil penelitian diperoleh nilai $t$ hitung untuk masing-masing variabel independent:

Pendapatan per kapita $\left(\mathrm{X}_{1}=\right.$ 1,502330), sektor industri $\left(\mathrm{X}_{2}=\right.$ $0,810945)$, sektor perdagangan $\left(\mathrm{X}_{3}=\right.$ $4,21199)$, sektor akomodasi dan penyedia makanan minumam $\left(\mathrm{X}_{4}=2.8585\right)$, sektor informasi dan komunikasi $\left(\mathrm{X}_{5}=2.76456\right)$. Dan nilai propobabilitas: pendapatan per kapita $\left(\mathrm{X}_{1}\right)$ sebesar 0,1438; sektor industri sebesar 0,4240; sektor perdagangan sebesar 0.0002 ; sektor akomodasi dan penyedia makanan minuman sebesar 0,0071; dan sektor informasi dan komunikasi sebesar 0,0098 .
Nilai t-hitung pendapatan per kapita dan nilai t-hitung sektor industri lebih kecil dari t-tabel $(1,645)$ dan nilai probabilitas pendapatan per kapita dan nilai probabilitas sektor industri lebih besar dari $\alpha(0,05)$ maka disimpulkan bahwa kedua variabel ini berpengaruh tetapi tidak signifikansi terhadap kapasitas pajak daerah.

Nilai t-hitung sektor perdagangan; nilai thitung sektor akomodasi dan penyedia makanan minuman dan nilai t-hitung sektor informasi dan komunikasi lebih besar dari t-tabel $(1,645)$ dan nilai probabilitas ketiga variabel ini lebih kecil dari $\alpha$ $(0,05)$ maka dapat disimpulkan bahwa sektor perdagangan, sektor akomodasi dan penyedia makanan minuman, sektor informasi dan komunikasi berpengaruh secara signifikansi terhadap kapasitas pajak daerah.

Pengaruh sektor perdagangan secara signifikansi tetapi bersifat negatif. Pengaruh secara negatif menunjukkan bahwa sektor perdagangan terutama perdagangan besar bukan merupakan sumber penerimaan bagi pajak daerah. Sehingga semakin tinggi nilai sektor perdagangan maka akan semakin berkurang penerimaan pajak daerah.

Pendapatan perkapita dan sektor industri walaupun pengaruhnya tidak signifikansi terhadap terhadap pajak daerah, namun kedua variabel ini bisa menjadi potensi bagi penerimaan pajak daerah.

Sektor akomodasi dan penyedia makanan minuman dan sektor informasi dan komunikasi berpengaruh secara signifikansi terhadap pajak daerah. Ini berarti kedua variabel ini merupakan sumber utama yang potensial bagi pajak daerah.

\section{KESIMPULAN DAN SARAN}

\section{Kesimpulan.}

Berdasarkan hasil dan pembahasan di atas, maka kesimpulan hasil penelitian in adalah sebagai berikut: 


\section{Elastisitas - Jurnal Ekonomi Pembangunan \\ Vol. 3 No. 2, September 2021}

a. Pendapatan per kapita dan sektor industri berpengaruh secara tidak signifikansi terhadap pajak daerah. Hal ini ditunjukkan oleh nilai t-hitung lebih kecil dari t-tabel dan ditunjuki pula nilai probabilitas kedua variabel ini lebih besar dari $\alpha(0,05)$.

b. Sektor perdagangan berpengaruh secara signifikansi dan tidak searah terhadap pajak daerah. Hal ini ditunjukkan oleh t-hitungnya lebih besar dari t-tabel dan ditunjuki pula oleh nilai probabilitas nya lebih kecil dari $\alpha$ $(0,05)$.

c. Sektor akomodasi dan penyedia makanan minuman dan sektor informasi dan komunikasi berpengaruh secara signifikansi terhadap pajak daerah. Ini ditunjukkan oleh nilai t-hitung lebih besar dari t-tabel. Dan ditunjukan pula oleh nilai probabilitasnya lebih kecil dari $\alpha(0,05)$.

\section{Saran}

a. Perlu dilakukan penelitian dengan menggunakan factor-faktor lain yang mempengaruhi pajak daerah karena factor-faktor yang digunakan dalam penelitian ini pengaruhnya sangat kecil, kurang dari $10 \%$.

b. Dalam penelitian ini tidak dimaksukan faktor jumlah wajib pajak daerah dan jumlah sumber pajak daerah, maka dalam penelitian lebih lanjut kedua factor ini perlu dipertimbangkan sebagai factor yang mempengaruhi pajak daerah.

\section{REFERENSI}

Edwar, Deden Yoken Bernadi, 2020. Analisis Potensi, Efektivitas Pemungutan Dan Kontribusi Pajak Hotel Terhadap Penerimaan Pajak Daerah Di Kabupaten Bandung. http://dx.doi.org/10.30656/jak.v7i1 .1443
Ering, Sherly, dkk. 2016. Analisis Potensi Pajak Untuk Peningkatan Kapasitas Fiskal Kabupaten dan Kota Sulawesi Utara. Jurnal Ekonomi dan Pembangunan Indonesia. DOI:http//dx.doi.org/10.21002/je pi.v17i1.660

Gebriany Pirade Wenur, dkk (2016). Analisis Potensi Pajak Daerah Dalam Peningkatan Pendapatan Asli Daerah di Kota Bitung. https://media.neliti.com/media/publications/71432-ID-analisis-potensi-pajak-daerah-

Mardiasmo. 2013. Perpajakan Edisi Revisi. Penerbit ANDI Yogyakarta

Nazir, Moh, 2011. Metode Penelitian, Ed. Ke 7, Bogor, Ghalia Indonesia

Sumarsan, Thomas. 2013. Perpajakan Indonesia.: Pedoman Perpajakan Indonesia Lengkap

Undang - Undang Nomor 28 Tahun 2009 tentang Pajak Daerah dan Retribusi Daerah. 